\title{
The factors influencing of Consumer behavior at Thasadet Market in Nong Khai Province, Thailand
}

\author{
Nitipon Putachote \\ Faculty of Business Administration and Accountancy Khon Kaen University, Thailand
}

\begin{abstract}
The purposes of this research were (1) to study the factors of consumer behavior at Thasadet market in Nongkhai province, Thailand (2) to examine factors influencing consumers' purchase decision making. The data from 385 questionnaires were analyzed and processed by computer. Statistical analyses include percentage, frequency, and standard deviation. The results of the study a as follows: The majority of consumers were female, 21-30 years old, bachelor's degree holders, married, working in company with 15,001-20,000 Baht income. The majority of consumer purchase was souvenirs, the reasons of buying were gifts or present, purchase 2-3 times, buying day on Saturday and Sunday with the average expenses 501 1,000 Baht. In terms of consumers' opinion toward the impacts of marketing mix factors, it is found that product, price, place highly while promotion moderately impact on consumers' decision making.
\end{abstract}

\section{Key words: Consumer behavior, Factors influencing, Thasadet Market}

\section{INTRODUCTION}

Thasadet Market is a famous market in Asian. It is in Nong Khai province a border town of Thailand and Lao, it is on the bank of the Mekong River. This province is a gateway to Vientiane, the capital of the Lao people's Democratic republic (Lao PDR.).

Tha Sadet Market in the northeastern province of Nong Khai as one of the "must-see" markets in Thailand. Tha Sadet market sits on the western banks of the Mekong River The market will be promoted as a major tourist attraction to generate income for the local community. Many unique products of Nong Khai are on sale in this market, such as consumer goods and handicrafts.

The project promoting the country's must-see markets is in line with the Government's policy of establishing community markets, both for general products and those unique to each province, in order to serve as distribution channels for local traders. The Ministry of Commerce has found that Tha Sadet Market has great potential and is an attractive market for both Thai and foreign tourists, especially those from neighboring countries.

This Market is essentially the main pier for the ferry across the Mekong River to Tha Dua in Lao. However Thasadet Market has also become the focal point for local trade between this part of Thailand and neighbouring Lao. The products sold in Thasadet Market are from Asian counties like China, Lao, Cambodia, Myanmar, Vietnam and
Thailand. There are a lot of shops and products such as electrical, clothing, local handicraft, Thai silk, basketry, jeweler, cosmetics, leather, watches, ceramics, silver, foods and also wonderful souvenirs.

According to Thai-Laos trade through customs houses in northeastern region, Foreign Trade Department statistics.[1] Border trade in Thasadet Market between Thailand and neighboring countries totaled 639.16 billion baht last year, down $10.4 \%$ from a year earlier because of the effects of the global recession. Thailand's overland exports fell $10.8 \%$ to 366.11 billion baht and imports were down $9.8 \%$ to 273.04 billion. Cross-border trade between Thailand and Lao was totaled 71.98 billion baht in 2009 , a drop of $12 \%$. But the value of cross-border trade between Thailand and Laos is forecast to reach 80 billion baht at the end of this year, as the Thai government is pursuing a new strategy to optimize free trade agreements.

\section{LITERATURE REVIEWS}

The market is a group of individuals or organizations, or both that need products in a given category and that have the ability, willingness, and authority to purchase such products. The people or organization must want the product they must be able to purchase the product by exchanging money, goods, or service for it. They must be willing to use 
their buying power. They must be socially and legally authorized to purchase the product. Markets are broadly classified as consumer or business to business markets. These classifications are based on the characteristics of the individual and organizations within cash market. Because marketing efforts vary depending on the intended market, marketers should understand the general characteristics of these two groups [2].

According to Zeithaml, Bitner and Gremer, they explained, services are deeds, processes and performances provided or coproduced by one entity or person for another entity or person. The service are not tangible things that can be touched, seen, and felt, but rather are intangible deeds and performances provided or coperduced for its customers.[3]

The consumer behavior is a function of the interactions of interpersonal influences such as culture, friends, classmates, co-workers, and relative, and personal factors such as attitudes, learning, and perception.[4]

The consumer behavior is defined as the behavior that consumers display in searching for purchasing, using, evaluating and disposing of products and services that they expect will satisfy their needs. Consumer behavior focuses on how individuals make decisions to spend their available resource such as time, money, effort on consumptions related items. That includes what they buy, why they buy, when they buy, where they buy, how often they buy, how often they use, how they evaluate it after the purchase and the impact of such evaluations on future purchase and how they dispose of it.[5]

The consumer decision process consists of five stages as following (1) need recognition the need can be triggered by internal stimuli when one of the person's normal needs and rises to a level high enough to become a drive. A need can also be triggered by external stimuli such as advertisement or discussion with friend might get you thinking about buying a new product. The marketer should research consumers to find out what kinds of needs or problems arise what brought them about, and how they led the consumer to this particular product. (2) Information search, an interested consumer may or may not search for more information. If the consumer's drive is strong and satisfying product is near at hand. The consumer is likely to buy it then, if not the consumer may store the need in memory or undertake an information search related to the need when consumer have decided their need a new product at the least they will probably pay more attention to new product. Consumer can obtain information from any of several sources. These include personal sources, commercial sources, Web sites, public sources, experiential sources varies with the product and the buyer. As more information is obtained the consumer's awareness and knowledge of the available brands and features increase. The information might also help them to drop certain brands from consideration. A company must design its marketing mix to make prospects aware of and knowledgeable about its brand.it should carefully identify consumers' sources of information and the importance of each source. (3) Evaluation of alternative the buyer decision process in which the consumer uses information to evaluate alternative brands in the choice set. The consumer arrives at attitudes toward different brands through some evaluation procedure. How consumers go about evaluating purchase alternatives depends on the individual consumer and the specific buying situation. In some cases consumers use careful calculations and logical thinking. At other time, the same consumers do little or no evaluating instead they buy on impulse and rely on intuition. Sometime consume make buying decisions on their own, sometime they turn to friends consumer guides or salespeople for buying advice. However marketers should study buyers to find out how they actually evaluate brand alternatives of they know that evaluative processes go on marketer can take steps to influence the buyer's decision. (4) Purchase decision, in the evaluation stage the consumer ranks brands and forms purchase intentions. Generally the consumers' purchase decision will be to buy the most preferred brand but two factors can come between the purchase intention and the purchase decision. The first factor is the attitudes of others. If someone important to them thinks that they should buy the lowest price. The second factor is unexpected situational factors. The consumer may form a purchase intention based on factors such as expected income, expected price, expected product benefits. However unexpected events may change the purchase intention.(5) Post purchase behavior, after consumer purchase the product the consumer will be satisfied or dissatisfied and will engage in post purchase behavior of interest to the marketer. What determines whether the buyer is satisfied or dissatisfied with a purchase, if the product falls short of expectations, the consumer is dissatisfied but if it meets expectations the consumer is satisfied , if it exceeds expectation the consumer is delighted.[6]

The marketing mix is the set of controllable, tactical, market tools that the firm blends to produce the response it wants in the target market. In addition the firm has control over such organizational resources as finances and information. These resources may be used to accomplish market goal. However the firm's marketing activities are also affected by a of external and generally uncontrollable. [7]

The service marketing mix consists of the variables product element, place and time, price, promotion, process, physical environment, people, productivity and quality, well known the 8 Ps or eight elements. 
Service marketing mix represent the ingredients required to create viable strategies for meeting customer needs profitably in a competitive marketplace. The 8Ps of service marketing are as following. (1) Product elements are the heart of a firm's marketing strategy. If a product is poorly designed it won't meaningful value for consumer even if the rest of the 8 Ps are well executed. Service product consist of a core product that responds to the consumers' primary need and array of supplementary service element that help consumer to use the core product effectively as well as adding value through welcomed enhancements. (2) Place and time or delivering product elements to consumers involve decision on where and when the former are delivered to the latter as well as the methods and channels employed. Delivery may involve use of physical or electronic channels depend on nature of the service. Use of messaging services and the internet allows information based services to be delivered in cyberspace for retrieval.(3) Price refers to the money value that the consumers have to pay to buy the product or service. The value inherent in payments is central to marketing's role in facilitating is the financial mechanism though which income is generated to offset the costs of providing service and create a surplus for profits.(4) Promotion refers to activities of personal selling, advertising, communicating product benefits and attributes to target consumers to persuade them to purchase. In service marketing much communication is educational in nature, especially for new consumer. Supplier need to teach these consumers about the benefits of the service, where and when to obtain it and how to participate in service processes to get the best results.(5)Process is a major objective of marketing to identify the need and wants in the marketplace, so that the organization may design the service of fulfill these needs. The concern extends to the design of the service process and the service delivery system, which are within the domain of operations. Ultimately the service and the process that creates it reflect how all the marketing mix elements are coordinated to create value for the consumer.(6) Physical environment is a appearance of buildings, landscaping, vehicles, interior furnishing, equipment, staff members, uniforms, sign ,printed materials and other visible cues all provide tangible evidence of a firm's service quality. Service firms need to manage physical evidence carefully because it can have a profound impact on consumers' impressions. (7) people, despite technology advances many services will always require direct interaction between consumers and contact personnel. The nature of these interactions strongly influences how consumers perceive service quality. Knowledge that satisfaction or dissatisfaction with service quality often reflects consumers assessments of staffs, successful of service firms devote significant effect to recruiting, training, and motivating employees. (8) Productivity and quality are often treaded separately, productivity and quality should be seen as two sided of the same coin. No service organization can afford to address one in isolation from the other. Improving productivity is essential to any strategy for reducing cost but managers must between of making inappropriate cuts in the service that will be resented by consumers. Improving quality which should be defined from a consumer perspective is essential for product differentiation and for building consumer satisfaction and loyalty. However it 's unwise to invest in service quality improvement without understanding the trade- off between incremental costs involved and the incremental revenues anticipated from offering better quality on specific dimension. If consumers aren't willing to pay extra for more quality then the firm will be lose money. [8]

\section{THE OBJECTIVES OF THE STUDY}

1. To study consumer behavior at Thasadet Market in Nong Khai Province, Thailand.

2. To examine factors influencing consumers' purchase decision.

\section{METHODOLOGY}

The author decided to use quantitative research and use questionnaires to obtain data from Thai consumer at Thasadet market in NongKhai pronvince, Thailand. The sample consisted of 385 Thai consumers, who were buy product in Thasadet market and data were collected in April and May 2017. The research tools were in the questionnaire and statistical analysis include percentage, frequency, standard deviation.

\section{RESULT ANALYSES AND DISCUSSIONS}

\section{Consumer participants}

Out of selected $49.4 \%$ respondents were male, and $50.6 \%$ respondents were female, majority of consumer aged between 30- 39 years, responding $37.7 \%$, hold bachelor degree, representing $44.9 \%$, most of consumer married, representing $60 \%$, working in company, representing $20.5 \%$, most respondents have income 15,001-20,000 Baht per month, representing $37.1 \%$.

\section{The consumer behavior participants}

Table 1: The product categories of consumer purchase

\begin{tabular}{|l|l|l|l|}
\hline $\begin{array}{l}\text { Product } \\
\text { categories }\end{array}$ & Frequency & Percentage & Rank \\
\hline Souvenirs & 273 & 70.9 & 1 \\
\hline Clothing & 189 & 49.1 & 2 \\
\hline
\end{tabular}




\begin{tabular}{|l|l|l|l|}
\hline Electrical & 113 & 29.4 & 3 \\
\hline Snack & 104 & 27.5 & 4 \\
\hline Sweets & 86 & 22.6 & 5 \\
\hline Foods & 82 & 21.2 & 6 \\
\hline Ceramics & 73 & 18.9 & 7 \\
\hline $\begin{array}{l}\text { Local } \\
\text { handicrafts }\end{array}$ & 64 & 16.6 & 8 \\
\hline Cosmetics & 61 & 15.8 & 9 \\
\hline Any others & 33 & 8.6 & 10 \\
\hline
\end{tabular}

Form table 1, the majority of consumer purchase were souvenirs, representing $70.9 \%$, following are clothing, representing $49.1 \%$. Electrical, representing 29.4\%, Snack, representing 27.5\%. Sweet, representing $22.5 \%$. foods, representing 21.2 $\%$. Ceramics, representing $18.9 \%$. Local handicrafts, representing $16.6 \%$. Cosmetics, representing $15.8 \%$. and any others, representing $8.6 \%$.

Table 2: the reason of buying

\begin{tabular}{|l|l|l|l|}
\hline $\begin{array}{l}\text { The reason } \\
\text { of buying }\end{array}$ & Frequency & Percentage & Rank \\
\hline $\begin{array}{l}\text { For gifts or } \\
\text { present }\end{array}$ & 316 & 82.1 & 1 \\
\hline For user & 292 & 75.8 & 2 \\
\hline Lower price & 71 & 18.4 & 3 \\
\hline $\begin{array}{l}\text { Good } \\
\text { quality }\end{array}$ & 23 & 6 & 4 \\
\hline Any others & 19 & 4.9 & 5 \\
\hline $\begin{array}{l}\text { Good } \\
\text { packaging }\end{array}$ & 17 & 4.4 & 6 \\
\hline
\end{tabular}

From table 2, the majority reasons of buying were gifts or present, representing $82.1 \%$, following are for user, representing $75.8 \%$, lower price representing $18.4 \%$, good quality representing $6 \%$, any others representing $4.9 \%$ and good packaging representing $4.4 \%$

Table 3: the frequency of buying

\begin{tabular}{|l|l|l|}
\hline $\begin{array}{l}\text { Frequency of } \\
\text { buying }\end{array}$ & Frequency & Percentage \\
\hline First time & 68 & 17.7 \\
\hline $2-3$ times & 193 & 50.1 \\
\hline $4-5$ times & 76 & 19.7 \\
\hline $\begin{array}{l}\text { More than 5 } \\
\text { times }\end{array}$ & 48 & 12.5 \\
\hline Total & 385 & 100 \\
\hline
\end{tabular}

Base on table 3, the most respondents purchase 2-3 times, representing $50.1 \%$,following are $4-5$ times representing $19.7 \%$, first time representing $17.7 \%$, more than 5 times representing $12.5 \%$.

Table 4: Buying day

\begin{tabular}{|l|l|l|}
\hline Buying day & Frequency & Percentage \\
\hline $\begin{array}{l}\text { Saturday and } \\
\text { Sunday }\end{array}$ & 334 & 86.8 \\
\hline Monday to Friday & 39 & 10.1 \\
\hline Any others day & 12 & 3.1 \\
\hline Total & 385 & 100 \\
\hline
\end{tabular}

From table 4, it the most importance of buying day dimension is Saturday to Sunday, representing 86.8 $\%$, following are Monday to Friday, representing $10.1 \%$, and any others day, representing $3.1 \%$.

Table 5: the expensing per time

\begin{tabular}{|l|l|l|}
\hline $\begin{array}{l}\text { Expensing per } \\
\text { time }\end{array}$ & Frequency & Percentage \\
\hline $\begin{array}{l}\text { Lower than } 200 \\
\text { Baht }\end{array}$ & 56 & 14.5 \\
\hline $201-500$ Baht & 97 & 25.2 \\
\hline $501-1,000$ Baht & 146 & 37.9 \\
\hline $1,001-1,500$ Baht & 64 & 16.6 \\
\hline $1,501-2,000$ Baht & 14 & 3.6 \\
\hline $\begin{array}{l}\text { More than 2,000 } \\
\text { Baht }\end{array}$ & 8 & 2.1 \\
\hline Total & 385 & 100 \\
\hline
\end{tabular}

Table 5 indicated the majority of expenses were 5011,000 Baht, representing $37.9 \%$, following are 201 -500 Baht, representing 25.2\%, 1,001 - 1,500 Baht, representing $16.6 \%$, lower than 200 Baht, representing $14.5 \%, 1,501-2,000$ Baht, representing $3.6 \%$, and more than 2,000 Baht, representing $2.1 \%$

\section{The factors influencing consumers' purchase decision}

Table 6: the factors influencing consumers' purchase decision on product

\begin{tabular}{|l|l|l|l|}
\hline Product & Mean & S.D & Rank \\
\hline Product variety & 4.11 & 0.74 & 1 \\
\hline Product features & 3.78 & 0.68 & 4 \\
\hline Product quality & 3.69 & 0.69 & 5 \\
\hline Product packaging & 3.88 & 0.67 & 3 \\
\hline Product design & 3.95 & 0.76 & 2 \\
\hline
\end{tabular}

Table 6 explains that the majority perceived that the most importance of product dimension is product variety $($ mean $=4.11)$, following is product design $($ mean $=3.95)$, product packaging $($ mean $=3.88)$, product features $($ mean $=3.78)$, product quality $($ mea $=3.69$ ).

Table 7: the factors influencing consumers' purchase decision on price

\begin{tabular}{|l|l|l|l|}
\hline Price & Mean & S.D & Rank \\
\hline Good price & 3.46 & 0.65 & 2 \\
\hline Low price & 3.02 & 0.56 & 4 \\
\hline Show price & 3.15 & 0.76 & 3 \\
\hline Several price & 3.92 & 0.64 & 1 \\
\hline
\end{tabular}

Base on table 7 consumer strongly agree in several price $($ mean $=03.92)$, second is a good price (mean $=3.46)$, third is show price $($ mean $=3.15)$, and the least importance is low price $($ mean $=3.02)$. 
Table 8: the factors influencing consumers' purchase decision on place

\begin{tabular}{|l|l|l|l|}
\hline Place & Mean & & \\
\hline Good location & 3.89 & 0.67 & 4 \\
\hline Coverage & 4.11 & 0.69 & 2 \\
\hline Display & 4.15 & 0.65 & 1 \\
\hline Comfortable & 3.91 & 0.66 & 3 \\
\hline Transport & 2.01 & 0.86 & 5 \\
\hline
\end{tabular}

Table 8 indicated the majority perceived that the most importance of place dimension is display $($ mean $=4.15)$, following is coverage $($ mean $=4.11)$, comfortable $($ mean $=3.91)$, good location $($ mean $=$ $3.89)$, and transport $($ mean $=2.01)$.

Table 9: the factors influencing consumers' purchase decision on promotion

\begin{tabular}{|l|l|l|l|}
\hline Promotion & Mean & & Rank \\
\hline Advertising & 3.35 & 1.00 & 3 \\
\hline Sales promotion & 3.54 & 0.66 & 2 \\
\hline Sales force & 2.81 & 0.73 & 4 \\
\hline Public relations & 4.01 & 0.65 & 1 \\
\hline
\end{tabular}

From table 9, it indicated that the majority of respondent though that the most importance of promotion dimension is public relations (mean = 4.01 ), following is sales promotion (mean $=3.54$ ), advertising $(M=3.35)$, and sales force (mean = 2.81).

Table 10: the factors influencing consumers' purchase decision on people or staff

\begin{tabular}{|l|l|l|l|}
\hline People or staff & Mean & S.D & Rank \\
\hline $\begin{array}{l}\text { Staff with product } \\
\text { knowledge }\end{array}$ & 4.17 & 1.719 & 2 \\
\hline Good training & 3.55 & 0.662 & 4 \\
\hline Good service & 4.21 & 0.496 & 1 \\
\hline Helpful staff & 3.76 & 1.493 & 3 \\
\hline Good looking & 3.23 & 0.716 & 5 \\
\hline
\end{tabular}

As shown in table 10, the majority perceived that the most importance of people or staff dimension is good service (mean $=4.21$ ), following is staff with product knowledge (mean $=4.17$ ), helpful staff (mean $=3.76)$, good training $($ mean $=3.55)$, and good looking $($ mean $=3.23)$.

Table 11: the factors influencing consumers' purchase decision on process

\begin{tabular}{|l|l|l|c|}
\hline Process & Mean & S.D & Rank \\
\hline Standardize & 3.63 & .769 & 2 \\
\hline Flow of process & 3.35 & .731 & 3 \\
\hline Fast service & 4.02 & .746 & 1 \\
\hline Number of process & 3.23 & .892 & 4 \\
\hline
\end{tabular}

From table 11, it indicated that the majority of respondent though that the most importance of process dimension is fast service (mean $=4.02$ ). following is standardize (mean $=3.63$ ), flow of process $($ mean $=3.35)$, and number of process $($ mean $=3.23)$.

Table 12: the factors influencing consumers' purchase decision on Physical evidence

\begin{tabular}{|l|c|c|c|}
\hline Physical evidence & Mean & S.D & Rank \\
\hline Equipment & 4.02 & .744 & 1 \\
\hline Signage & 3.76 & .715 & 3 \\
\hline Environment & 3.83 & .547 & 2 \\
\hline Staff uniform & 3.62 & .842 & 4 \\
\hline
\end{tabular}

Table 12 indicated the majority perceived that the most importance of Physical evidence dimension is equipment (mean $=4.02$ ), following is environment $($ mean $=3.38)$, signage $($ mean $=3.76)$, and staff uniform ( mean $=3.62$ ).

Table 13: the factors influencing consumers' purchase decision on

\begin{tabular}{|l|l|l|l|}
\hline $\begin{array}{l}\text { Productivity } \\
\text { and quality of } \\
\text { service }\end{array}$ & Mean & S.D & Rank \\
\hline $\begin{array}{l}\text { Professionally } \\
\text { staff }\end{array}$ & 4.12 & 1.00 & 1 \\
\hline $\begin{array}{l}\text { Quality of } \\
\text { service }\end{array}$ & 4.02 & 0.66 & 2 \\
\hline $\begin{array}{l}\text { Customer } \\
\text { satisfactions }\end{array}$ & 3.76 & 0.73 & 3 \\
\hline $\begin{array}{l}\text { Solving } \\
\text { customer } \\
\text { problems }\end{array}$ & 3.65 & 0.65 & 4 \\
\hline
\end{tabular}

Base on table 13: indicated the majority perceived that the most importance of productivity and quality of service dimension is professionally staff (mean = 4.12 ), following is quality of service (mean $=4.02$ ), customer satisfaction ( mean $=3.76$ ), and solving customer problems $($ mean $=3.65)$.

\section{CONCLUSIONS}

1. Knowing the majority of respondents were female, aged between 21-30 years, hold bachelor degree, married, working in the company, with income 15,001 - 20,000 Baht per month

2. To understand consumer behavior, the most of respondents purchase were souvenirs, following are clothing, Electrical, Snack, Sweet, foods, Ceramics, Local handicrafts, Cosmetics, and any others, The reasons of buying were gifts or present, most respondents purchase 2-3 times, with the average expenses 501-1,000 Baht.

3. According to the results, consumers were strongly agree in product variety, several price, 
place dimension was display, and promotion significance was public relations.

In conclusion, it seems that consumers still need to improve the quality of marketing mix such as product element, place and time, price, promotion, process, physical environment, people, productivity and quality. Trade should emphasize on various forms of technology access by asking for support and cooperation from education institutions such as universities that have missions of providing service to society. The business should learn and adopt new knowledge and innovative techniques about product design, production process, service, etc. that can be applied to self-improve the entrepreneur leading to the generation of sustainable income and popularity of business.

For marketing strategy of Thasadet Market should pay attention to media advertising including Off Line and On Line, and perform public relation together with public sector or community of entrepreneurs in order to stimulating recognition and loyalty toward brand from customers. With regard to price, this business should give priority to specifying product price clearly. If there are many entrepreneurs who sell similar products, they should conduct price deal with each other in order to go in the same direction, in order to meet the consumers' satisfactions.

\section{REFERENCES}

[1] Foreign Trade Department statistics (20162017).Thai-Laos trade through customs houses in northeastern region.

[2] Pride, Hughes, Kapoor (2012). Introduction to Business, South-Western Cengage Learing, pp. 404-408

[3] Zeithaml, Biner, Gremler (2009). Service marketing Integrating Customer Focus Across the Firm, Mc Graw Hill, p. 4

[4] Kurtz.)2008(. Principles of contemporary Marketing.USA: Thomson Southwestern.

[5] Schiffman, Kanuk(2003).Consumer Behavior, Prentice Hall of India, P.8

[6] Phillips Kotler. ( 2009 ) Marketing Management : Analysis, Planning, Implementation and control. $13^{\text {th }}$ ed. New Jersey : Asimon \& Schuster.

[7] Pride, Hughes, Kapoor (2012). Introduction to Business, South-Western Cengage Learing, pp. 409-411

[8] Lovelock, Wirrtz (2007). Service Marketing people, technology, strategy,Pearson Prentice Hall,pp. 22-25 